\title{
Some Properties of a Gram-Negative Heterotrophic Marine Bacterium
}

\author{
BY A. D. BROWN \\ Marine Laboratory (C.S.I.R.O.), Cronulla, Sydney, Nerw South Wales, Australia
}

(Received 9 May 1960)

SUMMARY

Some properties of a marine bacterium are described. This organism belongs to a large, but ill-defined, group comprising Gram-negative rods with no apparent action on monosaccharides. It is a polar flagellate, has limited acid tolerance, consistent with its inability to produce acid from sugars and has no constitutive system for metabolizing glucose. A weak inducible system was available, however, which enabled adapted organisms to grow on glucose and use it as a respiratory substrate. The organism also lacks a constitutive citric acid cycle but ability to metabolize succinate was induced by growth on succinate or glucose. It cannot use inorganic nitrogen for growth. Of the compounds examined, amino acids were the most generally satisfactory sources of energy, carbon, and nitrogen. The organism accumulated a relatively large pool of intracellular amino acids which probably contributed largely to its high rate of endogenous respiration. The classification of the bacterium is discussed.

\section{INTRODUCTION}

A Gram-negative heterotrophic marine bacterium, recently isolated from eastern Australian waters, was selected for the study of some aspects of its biochemistry and physiology with particular reference to its macro-molecular components. To facilitate reference to the organism in the future and because its classification raises some problems, some general properties are described in the present paper. The organism belongs to a group of bacteria which in some environments is probably of considerable numerical importance. This group contains Gram-negative rods without apparent action on the commoner hexoses and pentoses. In this category are to be found bacteria which are non-motile, motile with peritrichous flagella, and motile with polar flagella. Descriptions of bacteria of the first two kinds are listed with the Achromobacteriaceae (Bergey's Manual, 1957), while descriptions of the polar flagellates are included in the Pseudomonadaceae and the Spirillaceae. The present organism is of this third kind, being motile by means of a single polar flagellum. The organism was chosen for a number of reasons; like many Gramnegative marine or halophilic bacteria it is very pleomorphic, it is readily susceptible to osmotic lysis (which offers a means of rupturing cells without the disadvantages of mechanical or sonic disintegration) and it is readily autolysed (suggesting the presence of enzyme(s) which might be useful in degrading the cell wall and associated structures). These properties suggested that the cell wall of the organism is weak and that its study might provide information of a kind less readily obtainable from other sources. These and other aspects of the organism will be discussed elsewhere. 
The properties examined were chosen (i) to give enough information about the organism to enable it to be recognized again; (ii) to give information about the principal mechanisms by which the organism obtains, or may obtain, its nutrients and energy. Under (i) is included the qualitative chemical composition of the cell wall. While there are as yet insufficient data to say whether cell-wall composition of the Gram-negative bacteria has any taxonomic significance, as it has for some Grampositive genera (Cummins \& Harris, 1956, 1958), it is undoubtedly one of the more suitable properties of most bacteria. Under (ii) emphasis has been placed on energyyielding mechanisms as there is good reason for regarding this kind of activity as one which provides one of the more rational biochemical bases for classifying organisms in a broad sense and for providing a background against which to consider their natural relationships to each other.

\section{METHODS}

Source and maintenance of the bacterium. The bacterium was isolated from a water sample taken about 5 miles off Port Hacking, N.S.W., Australia, from a depth of $50 \mathrm{~m}$., about $10 \mathrm{~m}$. above the sea-bed. It has been maintained with weekly transfers on sea water peptone agar (see below) at $20^{\circ}$. Attempts to freeze-dry cultures were unsuccessful, reconstitution of the dried material in a variety of solutions being accompanied by complete dissolution of the solid components of the cells.

Media. Media were prepared in sea water (collected from the sea or the Port Hacking estuary) or in an artificial sea water of the following composition (per 1.): NaCl, 24 g.; $\mathrm{MgCl}_{2} 6 \mathrm{H}_{2} \mathrm{O}, 11 \mathrm{~g}$.; $\mathrm{Na}_{2} \mathrm{SO}_{4}, 4 \mathrm{~g}$.; $\mathrm{KCl}, 0.7 \mathrm{~g}$; $\mathrm{CaCl}_{2}, 5 \mathrm{ml}$. of a $10 \%$ $\left(\mathrm{w} / \mathrm{v}\right.$ ) solution added with stirring; $\mathrm{Na}_{2} \mathrm{HPO}_{4}, 15 \mathrm{ml}$. of $0.2 \mathrm{M}$ solution added with stirring; $\mathrm{FeSO}_{4} .7 \mathrm{H}_{2} \mathrm{O}, 0.04 \mathrm{mg}$. Buffered artificial sea water contained phosphate buffer as described with the results.

Sea-water peptone and sea-water peptone agar contained per 1., $10 \mathrm{~g}$. Difco peptone and $2 \mathrm{ml} .0 \cdot 2 \mathrm{M}-\mathrm{Na}_{2} \mathrm{HPO}_{4}$; the media were adjusted to $\mathrm{pH} 7 \cdot 2-7 \cdot 4$. Such media were sterilized by autoclaving at $10 \mathrm{lb} . / \mathrm{in} .^{2}$ for 5-10 min. With Difco peptone, no precipitation occurred under these conditions. The compositions of various defined media, which were sterilized by filtration through Millipore membrane filters, are given with the appropriate results.

Unless designated 'stagnant', all cultures were grown with aeration. Cultures were grown at room temperature (20-25 ) unless otherwise stated. The term 'lag' in reference to growing cultures means the number of days from inoculation to the appearance of turbidity.

Cell-wall preparation and analysis. Cell walls were prepared by mechanical breakage in the Mickle disintegrator or by osmotic lysis followed by differential centrifugation (Salton \& Horne, 1951) and in some instances by tryptic digestion (Cummins \& Harris, 1956). Amino acid and amino sugar composition of cell walls was established by reaction with ninhydrin on 2-dimensional paper chromatograms run in $80 \%(\mathrm{v} / \mathrm{v})$ aqueous pyridine and butan-1-ol + acetic acid+water $(6: 1: 2, \mathrm{v}: \mathrm{v}: \mathrm{v})$ following hydrolysis in $6 \mathrm{~N}-\mathrm{NCl}$ for $16 \mathrm{hr}$. at $100^{\circ}$. Sugars were recognized as described with the appropriate results following hydrolysis in $2 \mathrm{~N}-\mathrm{HCl}$ for $2 \mathrm{hr}$. at $100^{\circ}$. Polyols (see Armstrong et al. 1959) were detected on paper chromatograms with the periodate + Schiff's base spray reagent of Buchanan, Dekker \& Iong (1950) after hydrolysis of cell walls as described with the results. Amino sugars were 
estimated by the method of Rondle \& Morgan (1955) following hydrolysis of the cell wall for $2 \mathrm{hr}$. in $2 \mathrm{~N}-\mathrm{HCl}$ at $100^{\circ}$.

Miscellaneous methods. Intracellular amino acids were estimated by the method of Cocking \& Yemm (1954). Determination of the mass of organisms for reference purposes in the estimation of amino acid pools and calculation of respiratory quotients was complicated by the need to wash them in salt or sucrose solutions to prevent osmotic lysis and by the fact that a significant amount of autolysis always occurred in the centrifuge, even in the presence of various protecting solutions. Amino acid pools and respiratory quotients were therefore referred to the weight of material precipitated in the cold by $5 \%(\mathrm{w} / \mathrm{v})$ trichloroacetic acid (TCA) and washed once with water. The precipitate was dried in vacuo over $\mathrm{H}_{2} \mathrm{SO}_{4}$. Checks on a terrestrial species of $P$ seudomonas treated in this way gave a ratio of dry weight of whole organisms: dry weight of TCA precipitate of 1:1.02.

Determinations of $\mathrm{O}_{2}$ uptake were made at $25^{\circ}$ (unless indicated otherwise) by conventional Warburg manometric methods.

Succinate was determined in artificial sea water media as follows. Sulphate and phosphate were removed by addition of $\mathrm{BaCl}_{2}$ and cations were removed on Amberlite IR-120(H). The solution was concentrated in a stream of hot air and finally evaporated to dryness under vacuum in the presence of $\mathrm{NaOH}$. In this way most of the $\mathrm{Cl}^{-}$was removed. The material was then chromatographed on a strip of Whatman 3 MM paper in butan-1-ol + acetic acid + water $(6: 1: 2, \mathrm{v}: \mathrm{v}: \mathrm{v})$ in which the $\boldsymbol{R}_{f}$ of succinic acid is about $\mathbf{0 . 7 3}$ and well ahead of the other anions present. The succinic acid was located by side markers, the strip plus suitable blanks and standards was cut out and soaked in a convenient volume of water. After about $30 \mathrm{~min}$. the filter paper suspension was titrated directly with $0.01 \mathrm{~N}-\mathrm{NaOH}$. The recovery of succinic acid by this method was about $96 \%$.

Glucose was estimated in artificial sea water media by the method of Somogyi (1952) after deionization with Amberlite IR-120(H) and IR-4B(OH).

Flagella were stained by the method of Leifson (1951) for which purpose it was necessary to suspend the organisms in sea water or an equivalent to prevent lysis. Other techniques are described with the appropriate results.

\section{RESULTS}

Cellular morphology. The organism in the logarithmic growth phase in an adequate medium showed rods with round ends, occurring mainly singly and in pairs. Under these conditions cellular dimensions were mainly within the range $\mathbf{1} \times \mathbf{1 . 5}$ $2 \mu$ with a minority of organisms as small as $1 \times 1 \cdot 2 \mu$ and as large as $1 \times 3.5 \mu$. Under other conditions of growth, e.g. in old cultures, a variety of shapes and sizes might be present. These variations included spherical forms of diameter from 1 to $5 \mu$, filamentous organisms and a variety of irregular shapes, illustrating the pleomorphism frequently attributed to marine bacteria (ZoBell, 1946). Logarithmicphase organisms were motile by means of a single polar flagellum and motility was frequently retained by the irregular forms. The organism is Gram-negative.

Colonial appearance. On sea water + peptone agar, colonies 1 to about 7 days old were circular, raised, slightly undulate, smooth and translucent. They might be off-white or yellow which in older cultures deepened to orange-red. On subculture, white 
and yellow colonies were maintained 'pure' for a time but eventually reverted to a mixture of both types. Conditions leading to the appearance of one kind or the other were not investigated. In addition to the yellow pigment, a diffusible brown to black pigment was formed in most media and under favourable conditions darkened the medium considerably. This pigment was shown to be melanin by incubating a suspension of the organisms with tyrosine, or better, by preparing the enzyme tyrosinase. This was done by extracting acetone- or freeze-dried organisms with water or phosphate buffer $(\mathrm{M} / \mathbf{1 5}, \mathrm{pH} 7)$. Partial purification was achieved by precipitating with saturated $\left(\mathrm{NH}_{4}\right)_{2} \mathrm{SO}_{4}$, dissolving the precipitate in water and adding acetone to a final concentration of $40 \%(\mathrm{v} / \mathrm{v})$. The acetone precipitate was discarded and the supernatant fluid which contained the enzyme was dialysed against running tap water. All these processes were carried out satisfactorily at $20^{\circ}$; frozen solutions of the enzyme were stable indefinitely. The activity of the enzyme was conveniently assayed by following the development of the pink intermediate substance (absorption maximum $475 \mathrm{~m} \mu$ ) formed by the action of the enzyme on tyrosine. The activity measured in this way was greatest near $\mathbf{p H ~ 5 . 5}$ but subsequent polymerization to melanin was faster at more alkaline $\mathrm{pH}$ values. As with tyrosinases from other sources, the enzyme required $\mathrm{Cu}^{++}$. Preparations from organisms grown in the presence of tyrosine or phenylalanine were 20-40 times more active than preparations from organisms grown without either of these amino acids.

Cell-wall composition. The amino acid composition of the cell wall is typical of Gram-negative bacteria, comprising, $\alpha, \epsilon$-diaminopimelic acid (DAP) and most of the amino acids normally found in protein hydrolysates. Amino sugars found were hexosamine and trace amounts of muramic acid (barely detectable with ninhydrin on paper chromatograms of hydrolysates of $2 \mathrm{mg}$. cell wall). Glucose was identified by reaction with aniline phthalate following paper chromatography in the butanol + acetic acid solvent, butan-1-ol + pyridine + water $(6: 4: 3, \mathrm{v}: \mathrm{v}: \mathrm{v})$ and ammoniacal water-saturated phenol. The presence of a heptose was established by the sulphuric acid-cysteine reaction of Dische (1953). According to the criteria of Davies (1957) this is thought to be either D-glycero-L-galacto- or D-glycero-D-galactoheptose. Spots corresponding to glycerol and some unidentified polyols were detected on paper chromatograms of acid hydrolysates $\left(2 \mathrm{~N}-\mathrm{HCl}\right.$ at $100^{\circ}$ for 2 and $22 \mathrm{hr}$. and $0.5 \mathrm{~N}-\mathrm{H}_{2} \mathrm{SO}_{4}$ at $100^{\circ}$ for $20 \mathrm{hr}$.) of cell walls run in propan-1-ol + ammonia $(15 \mathrm{~N})+$ water $(6: 3: 1, \mathrm{v}: \mathrm{v}: \mathrm{v})$ and the butanol + acetic acid solvent system. Cell walls from organisms which had been grown on peptone contained 1.4-1.6\% amino sugar (as glucosamine) but this value could be altered by varying the nutrient composition of the growth medium as will be described elsewhere.

Miscellaneous biochemical properties. Antibiotic sensitivity (after Shewan, Hodgkiss \& Liston, 1954) was examined by using 'Sentest' tablets (Evans Medical Supplies Ltd.). The organism was resistant to penicillin (2.5 international units)

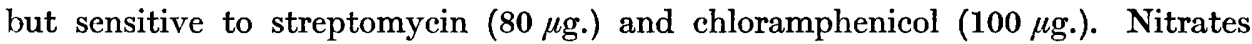
were reduced to nitrites. Gelatin was liquefied. Catalase was not formed. Acid was not produced from glucose. Ammonia was liberated during growth on peptone.

Miscellaneous biophysical properties. The organism grew over the approximate temperature range $10-40^{\circ}$. In an artificial sea water medium containing (g./l.) DLalanine, $2 \cdot 0$; glycine, $3 \cdot 0$; DL-lysine. $\mathrm{HCl}, 0 \cdot 4$; DL-methionine, $0 \cdot 4$; L-leucine, $0 \cdot 4$; 
$\mathrm{L}$-arginine. $\mathrm{HCl}, \mathbf{0} \cdot 4$ the growth rate was maximal at $35^{\circ}$ (measured at $5^{\circ}$ intervals), with a mean generation time of $\mathbf{1 . 8 5} \mathrm{hr}$. Appreciably higher growth rates occurred in media containing peptone. At about $40^{\circ}\left(40 \cdot 4^{\circ}\right)$ in this defined medium, the organism grew arithmetically instead of exponentially with the formation of filaments and variety of grotesque cell shapes. At temperatures below about $10^{\circ}$ growth ceased, the organisms lysed and, when tyrosine was present, additional amounts of melanin were formed on lysis.

The ability of the organism to grow in artificial sea water + peptone adjusted at intervals of $0.5 \mathrm{pH}$ units over the range $\mathrm{pH} 6.0-9 \cdot 0$ was examined. Growth was greatly inhibited at $\mathrm{pH} 6.5$, completely suppressed at $\mathrm{pH} 6$, but occurred normally at $\mathrm{pH} \mathbf{7}$ and above. In a series of transfers through progressive dilutions of artificial sea water containing $1 \%(\mathrm{w} / \mathrm{v})$ peptone, the organism, shortly after isolation, grew on the equivalent of $36 \%(\mathrm{v} / \mathrm{v})$ artificial sea water but not at $24 \%$ or lower; after about 1 year in culture it grew on $10 \%(\mathrm{v} / \mathrm{v})$ artificial sea water, but not at $5 \%$ or lower. It also grew readily in double strength artificial sea water containing $1 \%$ peptone. More concentrated media were not investigated.

Table 1. Ability of the marine bacterium to use selected amino acids $(1 \cdot 0 \%, w / v)$ and amino acid mixtures (total concentration $1.0 \%$, w/v) for growth in stagnant culture in artificial sea water

\begin{tabular}{|c|c|c|c|}
\hline No growth & Poor growth & Average growth & Good growth \\
\hline $\begin{array}{l}\alpha, \epsilon \text {-Diaminopimelic acid } \\
\text { L-Tryptophan }\end{array}$ & $\begin{array}{l}\text { Glycine } \\
\text { DL-Phenylalanine } \\
\text { L-Tyrosine }\end{array}$ & $\begin{array}{l}\text { DL-Alanine } \\
\text { L-Serine } \\
\text { L-Arginine } \\
\text { L-Aspartate } \\
\text { Alanine + serine }\end{array}$ & $\begin{array}{l}\text { L-Glutamate } \\
\text { Alanine + arginine } \\
\text { Serine + arginine }\end{array}$ \\
\hline
\end{tabular}

Nutrition. The nutritional requirements of the organism are simple but restricted. In general, amino acids were found to be adequate sources of carbon and nitrogen. Table 1 shows its ability to use selected amino acids and amino acid mixtures for growth. Growth on tyrosine or phenylalanine was slow and total crops were low but the organisms were of normal appearance. Growth on glycine did not always occur; total crops were very low (in stagnant cultures maximal optical density at $700 \mathrm{~m} \mu$ of $c .0 \cdot 04$ ), many of the organisms were grossly distorted and about 2 days after the appearance of turbidity such cultures underwent extensive lysis, no visible turbidity remaining.

Serine produced more rapid growth than alanine but a similar total crop. Aspartate and glutamate (singly) gave variable results; sometimes no growth occurred at all. The lag in stagnant cultures (inoculum, stationary phase sea-water peptone culture, 1 loop/10 ml.) was about 4 days with glutamate, compared with about 1 day for the amino acids in column 3 of Table 1 .

Preliminary observations showed that no growth occurred in the presence of $\mathrm{NH}_{4}{ }^{+}$ plus any of the following compounds : galactose, glucose, fructose, rhamnose, ribose, acetate, citrate, lactate, pyruvate or succinate. Selected carbon sources were then tested for their ability to stimulate growth in the presence of low concentrations of arginine $(0.025 \%, \mathrm{w} / \mathrm{v}$, of monohydrochloride). Under these conditions citrate, fructose and glycerol had no effect; glucose, galactose and lactate hastened the 
appearance of turbidity and caused slight increases (c. $20 \%$ in stagnant cultures) in total crop, while succinate markedly hastened the appearance of turbidity and increased the total crop. Chemical determinations showed disappearance of succinate (see below), failed to show any disappearance of glucose (see below); they were not made for lactate and galactose. An additional effect of glucose was apparent in older stagnant cultures. The total maximal crop on arginine + glucose was only about $20 \%$ more than on arginine alone but whereas the arginine control cultures subsequently underwent extensive lysis, the arginine + glucose cultures did not. The conditions were such that this was unlikely to be an osmotic 'stabilizing' effect.

With succinate or lactate as carbon source hydroxylamine, like ammonia, did not provide nitrogen for growth, but urea was readily used in conjunction with succinate after a lag of about 3 days (inoculum, 1 loop of stationary phase peptone culture/ $10 \mathrm{ml}$.$) .$

The ability of the organism to use glucose was confirmed as follows. Buffered artificial sea water $(0.025 \mathrm{M}$-phosphate buffer, $\mathrm{pH} 7 \cdot 2)$ containing urea $(0.25 \%$, $\mathrm{w} / \mathrm{v})$ and glucose $(0.5 \%, \mathrm{w} / \mathrm{v})$ was inoculated with 2 loops $/ 10 \mathrm{ml}$. of stationary phase cultures grown in the urea + succinate or arginine + glucose media. The organisms grown on arginine + glucose grew on urea + glucose after a lag of 1 day (in stagnant culture). Organisms grown on urea + succinate grew on urea + glucose after a lag of 10 days. In neither case was measurable acid produced in this medium. The organism did not grow on urea alone.

\section{Respiratory substrates}

Unless indicated otherwise, organisms were grown for manometric observations in $\mathbf{1 . 5} \mathrm{l}$. sea water + peptone for $24 \mathrm{hr}$. at $30^{\circ}$. They were washed twice and resuspended in artificial sea water $+0.05 \mathrm{~m}$-phosphate buffer $(\mathrm{pH} 7)$. Such organisms had a marked pink (cytochrome) colour and a high but somewhat variable rate of endogenous respiration which, after vigorous aeration for $4 \mathrm{hr}$. in buffered artificial sea water at $20-25^{\circ}$, could be decreased to about $60 \%$ of its former value. Osmotic lysis of freshly harvested organisms decreased the endogenous respiration rates by about $15 \%$ and the respiration rate of the lysed organisms was not appreciably different whether they were suspended in $0.05 \mathrm{M}$-phosphate buffer or in buffered artificial sea water.

On the other hand, respiration rates in the presence of oxidizable substrates were not high and the degree to which respiration was increased was markedly affected by the conditions under which the organism had been grown. Figure 1 shows respiration rates of the organism compared with those of a species of Pseudomonas (Brown, 1957) grown under approximately similar conditions, namely, 24 hr. at $30^{\circ}$ in $1 \%(\mathrm{v} / \mathrm{v})$ sea water containing $1 \%(\mathrm{w} / \mathrm{v})$ peptone.

Table 2 gives a list of substrates and the degree to which they stimulated respiration when used under the conditions of Fig. 1.

Amino acids. Alanine, which was one of the better substrates, was more obviously effective in organisms whose respiration had been decreased either by aeration in buffered artificial sea water or by growth in $\mathbf{5 0} \%(\mathrm{v} / \mathrm{v})$ sea water + peptone, which decreased endogenous respiration by about $45 \%$. Under these conditions increases in the absolute rates of oxygen uptake with alanine were also noted; the overall effect of the substrate was to stimulate respiration rate by about $200 \%$. 
It was thought that the relatively high endogenous respiration might be reflected in the intracellular amino acid pools; these were determined, therefore, on the marine organism and for comparison on the pseudomonad. For this purpose the bacteria were grown under the conditions of Fig. 1. The marine organism was washed twice in 0.5 M-sucrose containing 0.025 $\mathrm{m}$-phosphate buffer $(\mathrm{pH} 7)$ freeze-dried and extracted with suitable volumes of cold $5 \%(\mathrm{w} / \mathrm{v})$ TCA. The TCA was removed with

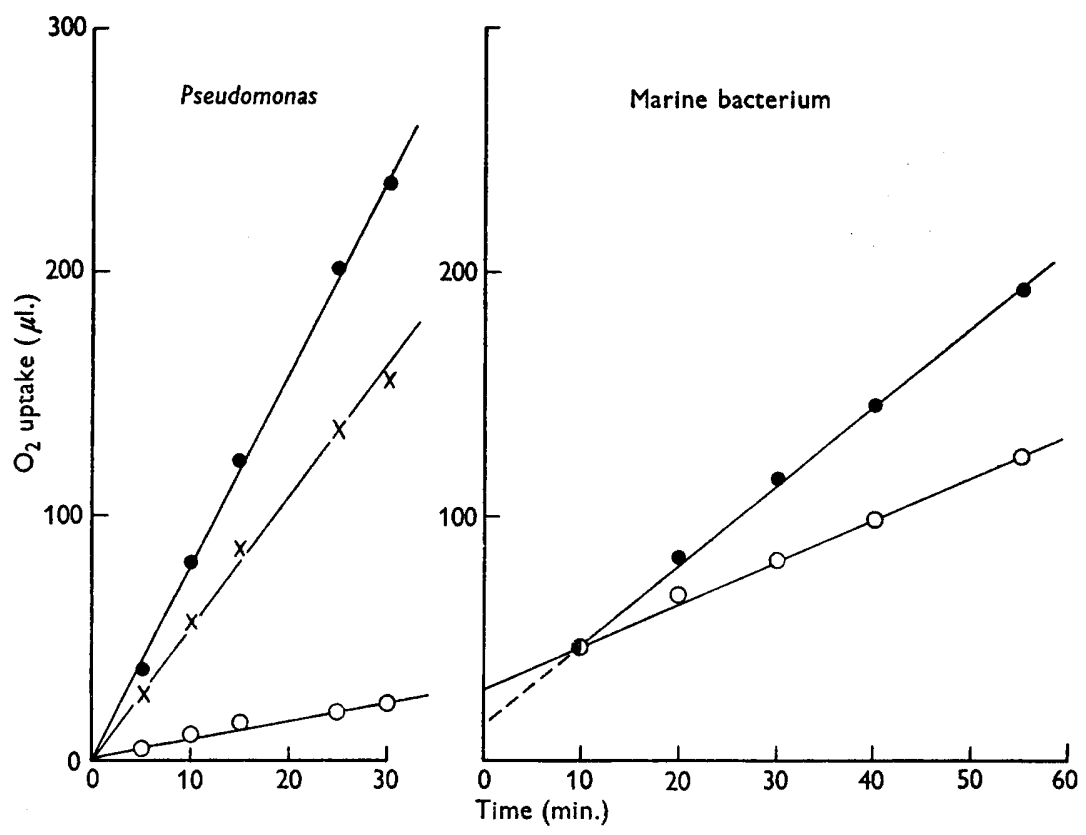

Fig. 1. Rates of oxygen uptake at $25^{\circ}$ by the terrestrial psychrophilic Pseudomonas sp. in the presence of DL-alanine or glucose and by the marine bacterium in the presence of DL-alanine. Flasks contained cells (equivalent to $2 \cdot 3 \mathrm{mg}$ TCA precipitate $/ \mathrm{ml}$. buffered artificial sea water), $1.00 \mathrm{ml}$; $0.5 \mathrm{M}$-phosphate buffer, $\mathrm{pH} 7,0.25 \mathrm{ml}$; substrate $(0.1 \mathrm{M}$, or $0.05 \mathrm{M}-\mathrm{NaCl}$ for endogenous), $0.25 \mathrm{ml}$; $\mathrm{KOH}$ in centre well. Absolute values of oxygen uptake are given, no correction being made for endogenous respiration. (Alanine, glucose, $x$; endogenous, 0 .)

Table 2. Ability of the marine bacterium, after growth on peptone, to use selected compounds $(0.017 \mathrm{M})$ as respiratory substrates

The figures represent the percentage increase of respiration above the endogenous rate at $25^{\circ}$

$\begin{array}{lclclc}\text { DL-Alanine } & \mathbf{4 4 - 8 0} & \text { Pyruvate } & 120 & \text { Glucose } & 0 \\ \text { L-Aspartate } & \mathbf{3 6 - 5 3} & \text { Lactate } & 53 & \text { Galactose } & 0 \\ \text { L-Glutamate } & \mathbf{5 3} & \text { Succinate } & 0^{*} & \text { Glucosamine } & \mathbf{0} \\ \text { Glycine } & \mathbf{2 5} & \text { Fumarate } & 0^{*} & \mathbf{N H}_{\mathbf{4}}^{+} & \begin{array}{c}-\mathbf{8 4} \\ \text { (inhibition) }\end{array} \\ \text { L-Serine } & \left(\text { at } 29^{\circ}\right) & & & & \\ & 180 & \text { Malate } & 0 & & \\ & & \alpha \text {-Ketoglutarate } & 0 & & \\ & & \text { Acetate } & 17 & & \\ & & \text { Glyoxylate } & 0 & & \end{array}$

* On one occasion succinate caused an increase of $47 \%$ after a lag of $190 \mathrm{~min}$. On another occasion fumarate caused an increase of $180 \%$ after a lag of 120 min. 
ether from the extract before amino acid analysis. (During harvesting and washing some of the organisms autolysed and the 'curd' of cell debris and viscous material (deoxyribonucleic acid) which collected above the pellet in the centrifuge tube was always discarded.) The pseudomonad was washed twice in $0.05 \mathrm{M}$-phosphate buffer

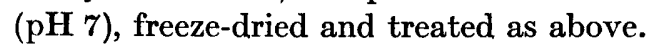

The marine bacterium contained $\mathbf{3 5 0} \mu$ mole glutamic acid equivalents/g. TCA precipitate compared with $100 \mu$ mole/g. for the pseudomonad. The identity of the amino acids in the extracts of both organisms is given in Table 3.

Citric acid cycle intermediates. The failure of citric acid cycle intermediates to stimulate respiration (except in the two cases of inducible utilization; Table 2) might imply the absence of this pathway from the marine organism. To establish whether or not such negative findings were caused by permeability effects, measurements of oxygen uptake rates in the presence of succinate were made on

\section{Table 3. Free amino acids in TCA extracts of the marine bacterium and the pseudomonad}

Marine bacterium

Alanine*
Aspartic acid
Glutamic acid
Leucine/isoleucine
Lysine
Phenylalanine
Proline
Valine/methionine

Pseudomonad

Alanine $\uparrow$

Aspartic acid

Glutamic acid

Lysine

\footnotetext{
* These amino acids accounted for nearly all the absorption at $570 \mathrm{~m} \mu$, compounds other than free amino acids contributing only to a minor extent. Aspartic acid, glutamic acid and alanine were the major components, while lysine was present in trace amounts.

$\dagger$ Glutamic acid was the predominant amino acid and was responsible for about $36 \%$ of the absorption at $570 \mathrm{~m} \mu$ (determined by eluting ninhydrin spots from the paper chromatogram with $75 \%(v / v)$ aqueous acetone). Aspartic acid and alanine contributed about $5 \%$ and $3 \%$ respectively. The major component was not a free amino acid, or at least not a known amino acid. It was not identified and represented about $52 \%$ of the total absorption. The remaining $4 \%$ of the total absorption was due to traces of unidentified compounds.
}

osmotically-lysed organisms. The organism was grown in sea water + peptone, harvested and washed as described above, lysed by suspending in cold $\mathbf{0 . 2 5} \mathrm{M}$ phosphate buffer ( $\mathrm{pH} 7$ ) mixed with an equal volume of double strength artificial sea water containing $0.025 \mathrm{M}$-phosphate buffer and diluted to the required concentration with buffered artificial sea water. The preparation of lysed organisms had no action on succinate. It seems improbable that excessive disorganization of electron transport systems occurred under these conditions, since the endogenous respiration remained at $85 \%$ of the rate for whole organisms (under Anoptral phase contrast all organisms were judged to have lysed) and respiration rates in the presence of aspartate were decreased only slightly by lysis.

Measurements of respiration rates in the presence of succinate and other substrates were made after growth of the organism under the following conditions: (1) $24 \mathrm{hr}$. at $30^{\circ}$ in sea water + peptone containing $0.5 \%(\mathrm{w} / \mathrm{v})$ succinic acid (disodium salt); (2) $45 \mathrm{hr}$. in phosphate-buffered (0.025, $\mathrm{pH}$ 7) $(\mathrm{v} / \mathrm{v})$ artificial sea 
water containing arginine (0.05\%, w/v; monohydrochloride) and succinate $(0 \cdot 1 \%$, $\mathrm{w} / \mathrm{v}$, succinic acid); (3) $7 \mathrm{hr}$. at $30^{\circ}$ from a heavy inoculum in $500 \mathrm{ml} .50 \%(\mathrm{v} / \mathrm{v})$ buffered artificial sea water containing arginine $(0.025 \%, \mathrm{w} / \mathrm{v}$; monohydrochloride) and $0.004 \mathrm{~m}$-succinate $(0.047 \%, \mathrm{w} / \mathrm{v}$, succinic acid). The inoculum was the centrifuged washed crop from 1.5 l. sea water + peptone medium grown overnight at $30^{\circ}$.

Organisms grown in the peptone medium showed no differences attributable to succinate. Succinate, fumarate, and malate each failed to stimulate respiration. After growth for $45 \mathrm{hr}$. in the arginine + succinate medium, $30 \%$ of the succinate was used without concomitant formation of detectable quantities of other carboxylic acids, the organisms were white (no cytochrome colour), the endogenous respiration rate was about $38 \%$ of that of organisms grown for $26 \mathrm{hr}$. on peptone, and neither succinate nor alanine had any effect on respiration.

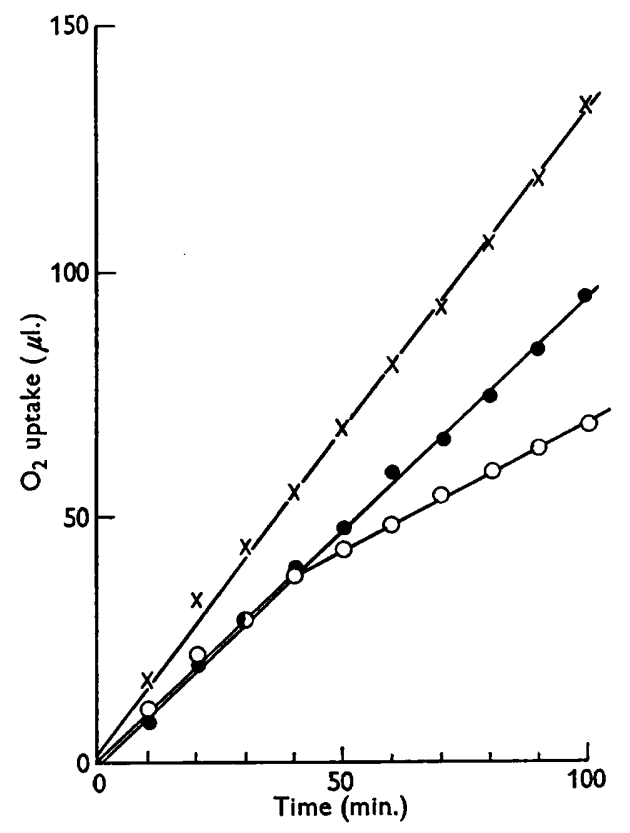

Fig. 2. Rates of oxygen uptake at $29^{\circ}$ of the marine bacterium in the presence of DL-alanine or succinate. The organism was grown for $7 \mathrm{hr}$. in the arginine + succinate medium and conditions, other than temperature, were as described for Fig. 1. Aspartate and malate (not shown) had no effect on respiration and glutamate stimulated respiration to the same extent as alanine. (Alanine, 0 ; succinate, $x$; endogenous, 0. .)

When the heavy inoculum was incubated in the arginine + succinate medium, all the succinate was used within $7 \mathrm{hr}$. and no other carboxylic acids detectable on paper chromatograms accumulated. The respiration of such organisms was stimulated by succinate as shown in Fig. 2.

Glucose. The ability of glucose to stimulate the respiration of organisms grown in other than peptone medium was tested as follows.

(1) A heavy inoculum such as described above was incubated at $30^{\circ}$ in buffered $50 \%(\mathrm{v} / \mathrm{v})$ artificial sea water containing arginine $(0.025, \mathrm{w} / \mathrm{v}$, monohydrochloride) and glucose $(0 \cdot 05, \mathrm{w} / \mathrm{v})$. Glucose determinations were made on the supernatant 
fluid sampled $3 \cdot 5$ and $7 \cdot 5 \mathrm{hr}$. after inoculation. Measurements of respiration rates were made on organisms harvested at $7 \cdot 5 \mathrm{hr}$. The following results and their standard deviations were obtained for the glucose determinations: initial sample, $0.468 \pm 0 \mathrm{mg}$. $/ \mathrm{ml}$.; $3.5 \mathrm{hr}$. sample, $0.436 \pm 0.010 \mathrm{mg} . / \mathrm{ml}$.; $7.5 \mathrm{hr}$. sample, $0 \cdot 444 \pm 0.023 \mathrm{mg} . / \mathrm{ml}$. Glucose and succinate had no effect on the respiration of the organisms harvested after $7 \cdot 5 \mathrm{hr}$., while alanine and acetate caused increases of similar magnitude to those listed in Table 2.

(2) The centrifuged crop from an overnight $30^{\circ}$ culture (1 l.) of the organism in sea water + peptone medium was suspended in $c .200 \mathrm{ml}$. of buffered artificial sea

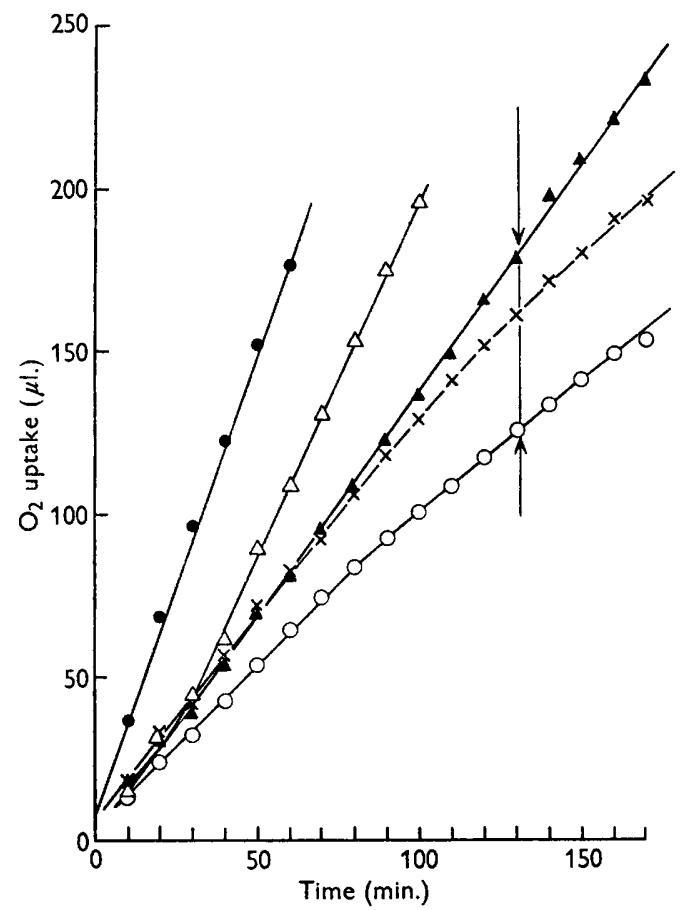

Fig. 3. Respiration rates at $26 \cdot 5^{\circ}$ of the marine bacterium after incubation for $24 \mathrm{hr}$. in a growth medium containing arginine and glucose. Values of oxygen uptake obtained in the presence of the added substrates, acetate, DL-alanine, glucose and succinate have not been corrected for the endogenous values. The arrow marks addition of iodoacetate to a final concentration of $0.001 \mathrm{M}$. Other conditions were described for Fig. 1. (Acetate, $\triangle$; alanine, ; glucose, $x$; succinate, $\Delta$; endogenous, $O$.)

water containing arginine (c. $0.05 \%, \mathrm{w} / \mathrm{v} ;$ monohydrochloride) and glucose (c. $0.05 \%, \mathrm{w} / \mathrm{v})$. After $24 \mathrm{hr}$. at $30^{\circ}$ determinations were made of glucose concentration in the culture fluid and of respiration rates in the presence of selected substrates. The following concentrations of glucose were found: initial sample, $0 \cdot 612 \pm 0 \cdot 055 \mathrm{mg} . / \mathrm{ml}$.; $24 \mathrm{hr}$. sample, $0 \cdot 606 \pm 0 \cdot 024 \mathrm{mg} . / \mathrm{ml}$.

The manometric results are shown in Fig. 3, from which it will be seen that both glucose and succinate caused a slight stimulation of respiration and acetate caused an increase of $113 \%$ over the endogenous rate (cf. Table 2). The slight change in slope of the glucose curve following addition of iodoacetate represents an inhibition of $40 \%$ of the rate of oxygen uptake after subtraction of endogenous values. 


\section{DISCUSSION}

It is clear from the results that the marine bacterium lacks a constitutive means of metabolizing glucose and that its inducible mechanism is not sufficiently vigorous to cause the disappearance of glucose in quantities large enough to be detected under the experimental conditions used. The ability of glucose-trained organisms to grow on glucose + urea, however, leaves little doubt about an actual consumption of glucose as distinct from a catalytic or physico-chemical stimulus which might otherwise have been held to account for the effects observed with this sugar. Acid production from carbohydrates other than glucose was not investigated as it was considered that the very limited acid tolerance of the organism would lead to a negative result in all such tests.

It is also apparent that the organism has no constitutive citric acid cycle but does have an inducible system for metabolizing succinate. Whether or not this system involves an inducible citric acid cycle has not been investigated but the evidence of Fig. 3 suggests that it might. The enhancement of acetate metabolism by growth on glucose and the induction by glucose of succinate metabolism are, at least, consistent with such a hypothesis. It should be noted, on the other hand, that growth on succinate did not lead to simultaneous induction of a system for malate respiration (Fig. 2), but in this case no account was taken of permeability.

The effect of ionic conditions on these two inducible systems (glucose and succinate) was not investigated (cf. Payne, 1958) but the ionic composition of growth, washing and suspending media was maintained at a level found adequate for good growth and hence, presumably, for the synthesis of inducible enzymes. Similarly, beyond comparing endogenous respiration of lysed organisms in dilute phosphate buffer (containing $\mathrm{Na}^{+}$and $\mathrm{K}^{+}$) and in artificial sea water, the effects of ionic conditions on respiration were not investigated (cf. Tomlinson \& McLeod, 1957); the assumption was made that ionic conditions suitable for good growth would be suitable for a survey of respiratory substrates.

Of the compounds tested, amino acids were the most satisfactory sources of carbon, nitrogen and energy. Utilization of at least some amino acids (e.g. alanine) evidently involved constitutive enzymes, notwithstanding the 2 days old organisms which were unable to metabolize either alanine or succinate. Other 3-C amino and carboxylic acids, namely serine, pyruvic and lactic acids were also good respiratory substrates, while the $2-\mathrm{C}$ amino acid, glycine was poor. Whole peptonegrown organisms cannot oxidize added glyoxylate (Table 2). If glycine is oxidized to glyoxylate as is likely (Kornberg \& Sadler, 1960), a block at glyoxylate could explain the inadequacy of glycine as a single nutrient. The fact that some growth did occur on glycine is probably explained by the 'catalytic' activity of amino acids from the intracellular pool, and these amino acids also undoubtedly contributed to the high rate of endogenous respiration. It is of interest that growth in a medium of lower salt concentration decreased the endogenous respiration rate but not the total amount of pool amino acids extracted from a unit mass of TCAprecipitable material.

In attempting to classify the present organism the standard of reference and nomenclature used was Bergey's Manual (1957). As the classification of Gramnegative bacteria generally, and, in particular, genera of the Pseudomonadaceae, 


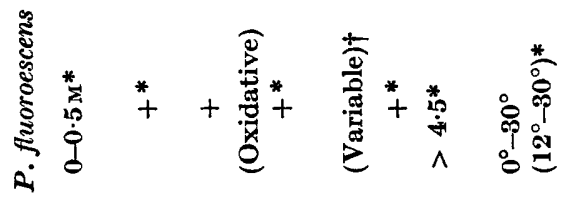
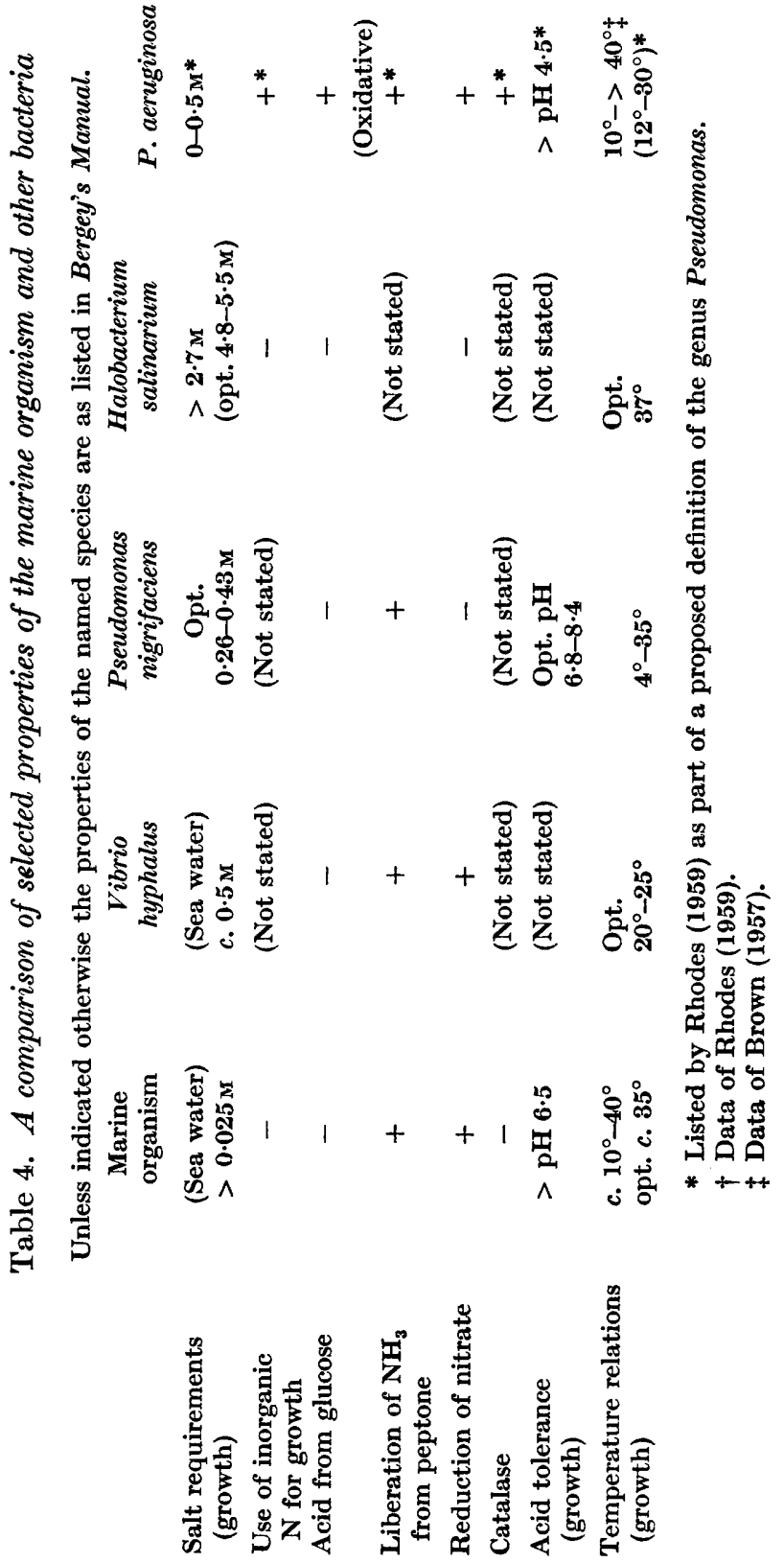
Spirillaceae, and Achromobacteriaceae is confused, however, this standard has been used with some reservations. Table 4 lists some properties of the present organism and similar organisms of three other genera from Bergey's Manual. Corresponding properties of Pseudomonas aeruginosa (the type species of the genus Pseudomonas) and $\boldsymbol{P}$. fluorescens are included for comparison. The present organism is sufficiently similar in these and other properties to Vibrio hyphalus and $\boldsymbol{P}$. nigrifaciens for it to be placed in either genus without causing any new anomalies. It is instructive to note that a selection of one of these genera in preference to the other involves a decision at the level of family and that, on the criteria of Bergey's Manual the decision must be made on whether or not, in the observer's opinion, the cells of the organism are curved. Gram-negative marine and halophilic bacteria are notoriously pleomorphic and it is doubtful whether the variations in size and shape which occur should be given any generic significance. Sea water is an effective stabilizing medium and it is reasonable to expect many Gram-negative bacteria which have evolved in marine or similar environments to have weak cell walls. This is evidently true of the present organism and the mechanical weakness of its walls is possibly reflected in their relatively low content of amino sugar (see Table 5). In this respect it is reminiscent of the spheroplasts to other Gram-negative bacteria.

Table 5. Amino sugar content of the cell walls of the marine organism and other Gram-negative bacteria

(Data for the other bacteria from Salton, 1958)

\begin{tabular}{|c|}
\hline $\begin{array}{c}\% \text { amino sugar } \\
\text { (as glucosamine) } \\
(2 \mathrm{~N}-\mathrm{HCl} \\
\text { hydrolysates) }\end{array}$ \\
\hline $1 \cdot 4-1 \cdot 6^{*}$ \\
\hline $2 \cdot 4-4 \cdot 0$ \\
\hline $6 \cdot 8$ \\
\hline $4 \cdot 2$ \\
\hline 2 \\
\hline $1 \cdot 9$ \\
\hline $4 \cdot 8$ \\
\hline $3 \cdot 9$ \\
\hline 13 \\
\hline
\end{tabular}

* The values quoted here are those obtained from organisms grown on peptone and are more comparable with Salton's figures than values for cell walls of organisms grown on various defined media. Amino sugar contents of cell walls of organisms grown on defined media, which will be described elsewhere, fell within the range $0 \cdot 97-2 \cdot 5 \%$

If the salt requirements of the genus Halobacterium were less rigidly defined, this genus could provide a convenient name for the marine bacterium since, in respect of its production of orange (presumably carotenoid) pigment, inability to produce acid from carbohydrates or use inorganic nitrogen for growth, its oxidation of various amino acids, and, of course, its pleomorphism the marine organism resembles $\boldsymbol{H}$. salinarium. The exclusion of the present organism from the halobacteria exemplifies a difficulty caused by delineating a genus by quantitative differences in a single physico-chemical property.

A classification of the organism must place it in the family Pseudomonadaceae. The selection of a genus is more difficult and in the writer's opinion is limited to 
the alternatives of (i) allocating the organism to the genus Pseudomonas, or (ii) creating a new genus. Bergey's Manual (1957) lists the genus Pseudomonas under section I of the family Pseudomonadaceae together with bacteria which 'attack glucose and other sugars either oxidatively or fermentatively'. The type species of the genus, $\boldsymbol{P}$. aeruginosa, oxidizes glucose vigorously and will grow on inorganic nitrogen (plus a suitable source of carbon) as will $\boldsymbol{P}$. fluorescens, a representative of a second important type of pseudomonad. While variations in any 'single' property must be expected within any defined group of organisms, a vigorous constitutive oxidative carbohydrate metabolism and an ability to grow on inorganic nitrogen carry such far-reaching implications about the biochemistry and physiology of the organisms, that when they are correlated with the other features of pseudomonads, namely Gram-negative staining, polar flagellation and an obligately aerobic physiology, they provide the basis of a precise and comprehensive definition which should not be lightly ignored. Hugh \& Leifson (1953) have already discussed the taxonomic importance of oxidative as distinct from fermentative carbohydrate metabolism; Brown \& Weidemann (1958) found that the use of this criterion, together with that of resistance to penicillin, provided the only effective means of classifying a number of non-motile species of Pseudomonas.

There is, of course, precedent for ignoring these properties. Having described the genus as quoted above, Bergey's Manual goes on to include in the genus species (e.g.Pseudomonas nigrifaciens, $\boldsymbol{P}$. gelatica and $\boldsymbol{P}$. halestorga) which are without apparent action on sugars (use of inorganic nitrogen is not recorded in these cases). The precedent is one which the present writer prefers not to follow, however, as it is the support of this practice which has produced the situation where the genus Pseudomonas may be logically distinguished from Vibrio only by a minor difference in the shape of the cell. The writer feels inclined therefore to advocate either the removal of all barriers so that all Gram-negative polar flagellates are called by the same generic name, or perhaps more reasonably, the creation of a new genus which would include the present organism and others e.g. Vibrio hyphalus, P. nigrifaciens and Halobacterium salinarium. It is, however, premature to formulate a definite proposal to this effect without an examination in the terms of this paper of a number of other similar organisms from various sources. It is hoped that further work will show whether such an opinion is justified. In the meantime the organism is left unnamed and will be referred to elsewhere by its number in the culture collection of these laboratories, marine pseudomonad no. 11.

\section{REFERENCES}

Armstrong, J. J., Baddiney, J., Buchanan, J. G., Davidson, A. L., Kelemen, M. V. \& Neuhaus, F. C. (1959). Teichoic acids from bacterial walls. Nature, Lond. 184, 247.

Bergey's Manual of Determinative Bacteriology (1957). 7th ed. Edited by R. S. Breed, E. G. C. Murray \& N. R. Smith. Baltimore: The Williams and Wilkins Co.

Brown, A. D. (1957). Some general properties of a psychrophilic pseudomonad: the effects of temperature on some of these properties and the utilization of glucose by this organism and Pseudomonas aeruginosa. J. gen. Microbiol. 17, 640.

Brown, A. D. \& Weidemann, J. F. (1958). The taxonomy of the psychrophilic meat spoilage bacteria: a reassessment. J. appl. Bact. 21, 11.

Buchanan, J. G., Dekker, C. A. \& Long, A. G. (1950). The detection of glycosides and non-reducing carbohydrates in paper-partition chromatography. J. chem. Soc. p. 3162. 
Cocking, E. C. \& Yemm, E. W. (1954). Estimation of amino acids by ninhydrin. Biochem. J. 58, xii.

Cummins, C. S. \& Harris, H. (1956). The chemical composition of the cell wall in some Gram-positive bacteria and its possible value as a taxonomic character. J. gen. Microbiol. 14, 583.

Cummins, C. S. \& Harris, H. (1958). Studies on the cell-wall composition and taxonomy of Actinomycetales and related groups. J. gen. Microbiol. 18, 173.

Davies, D. A. L. (1957). The identification of aldoheptose sugars. Biochem. J. 67, 253.

Dische, Z. (1953). Qualitative and quantitative colorimetric determination of heptoses. J. biol. Chem. 204, 983.

Hugh, R. \& Leirson, E. (1953). The taxonomic significance of fermentative versus oxidative metabolism of carbohydrates by various Gram-negative bacteria. J. Bact. 66, 24 .

Kornberg, H. L. \& SAduer, J. R. (1960). Microbial oxidation of glycollate via a dicarboxylic acid cycle. Nature, Lond. 185, 153.

Leifson, E. (1951). Staining, shape and arrangement of bacterial flagella. J. Bact. 62, 377.

Payne, W. J. (1958). Studies on bacterial utilization of uronic acids. III. Induction of oxidative enzymes in a marine isolate. J. Bact. 76, 301.

Rhodes, M. E. (1959). The characterization of Pseudomonas fluorescens. J. gen. Microbiol. 21, 221.

Rondle, C. J. M. \& Morgan, W. T. J. (1955). The determination of glucosamine and galactosamine. Biochem. $J .61,586$.

Salton, M. R. J. (1958). The lysis of micro-organisms by lysozyme and related enzymes. J. gen. Microbiol. 18, 481.

Salton, M. R. J. \& Horne, R. W. (1951). Studies on the bacterial cell wall. II. Methods of preparation and some properties of cell walls. Biochem. biophys. acta, 7, 177 .

Shewan, J. M., Hodgkiss, W. \& Liston, J. (1954). A method for the rapid differentiation of certain non-pathogenic asporogenous bacilli. Nature, Lond. 173, 208.

Soмоgуі, M. (1952). Notes on sugar determination. J. biol. Chem. 195, 19.

Tombinson, N. \& MAClEod, R. A. (1957). Nutrition and metabolism of marine bacteria. IV. The participation of $\mathrm{Na}^{+}, \mathrm{K}^{+}$, and $\mathrm{Mg}^{++}$salts in the oxidation of exogenous substrates by a marine bacterium. Canad. J. Microbiol. 3, 627.

ZoBeld, C. E. (1946). Marine Microbiology. Waltham, Mass.: Chronica Botanica Press. 